\title{
Applications of Satellite Remote Sensing to Water Governance and the Mitigation of Climate Change Effects
}

\author{
Senior Thesis
}

\author{
Ilham Ali ${ }^{1}$, James Famiglietti, $\mathrm{PhD}^{2}$, Jonathan McLelland, RA LEED BD+C ${ }^{3}$ \\ ${ }^{1}$ Department of Civil, Construction, and Environmental Engineering, College of Engineering, The University of Alabama \\ ${ }^{2}$ Global Institute for Water Security, School of Environment and Sustainability, The University of Saskatchewan \\ ${ }^{3}$ The Honors College and The New College, The University of Alabama \\ Submitted 01 May 2019
}

\begin{abstract}
Water stress in both surface and groundwater supplies is an increasing environmental and sustainable management issue. According to the UN Environment Program, at current depletion rates almost half of the world's population will suffer severe water stress by 2030. This is further exacerbated by climate change effects which are altering the hydrologic cycle. Understanding climate change implications is critical to planning for water management scenarios as situations such as rising sea levels, increasing severity of storms, prolonged drought in many regions, ocean acidification, and flooding due to snowmelt and heavy precipitation continue. Today, major efforts towards equitable water management and governance are needed. This study adopts the broad, holistic lenses of sustainable development and water diplomacy, acknowledging both the complex and transboundary nature of water issues, to assess the benefits of a "science to policy" approach in water governance. Such negotiations and frameworks are predicated on the availability of timely and uniform data to bolster water management plans, which can be provided by earth-observing satellite missions. In recent decades, significant advances in satellite remote sensing technology have provided unprecedented data of the Earth's water systems, including information on changes in groundwater storage, mass loss of snow caps, evaporation of surface water reservoirs, and variations in precipitation patterns. In this study, specific remote sensing missions are surveyed (i.e. NASA LANDSAT, GRACE, SMAP, CYGNSS, and SWOT) to understand the breadth of data available for water uses and the implications of these advances for water management. Results indicate historical precedent where remote sensing data and technologies have been successfully integrated to achieve more sustainable water management policy and law, such as in the passage of the California Sustainable Groundwater Management Act of 2014. In addition, many opportunities exist in current transboundary and interstate water conflicts (for example, the Nile Basin and the Tri-State Water Wars between Alabama, Georgia, and Florida) to integrate satellite-remote-sensed water data as a means of "joint-fact finding" and basis for further negotiations. The authors argue that expansion of access to satellite remote sensing data of water for the general public, stakeholders, and policy makers would have a significant impact on the development of science-oriented water governance measures and increase awareness of water issues by significant amounts. Barriers to entry exist in accessing many satellite datasets because of prerequisite knowledge and expertise in the domain. More user-friendly platforms need to be developed in order to maximize the utility of present satellite data. Furthermore, sustainable co-operations should be formed to employ satellite remote sensing data on a regional scale to preempt problems in water supply, quantity, and quality.
\end{abstract}




\section{Introduction}

\section{Overview}

Water is a vital source of life and supply to communities in every corner of the world. Of the two-thirds of Earth's surface that is dominated by water, only less than $3 \%$ is freshwater and a majority of this is still captured and largely inaccessible in glaciers. Remaining freshwater supplies - namely, surface water, groundwater, seasonal snowmelt, soil moisture, and precipitation are expected to provide for all domestic drinking water, gray water uses, agriculture demands, and industry production needs. Compounded by climate change effects and population growth, water stress is increasing globally and poised as a central issue into the foreseeable future. As the UN Environment Program estimate, at current depletion rates almost half of the world's population will suffer severe water stress by 2030 . Climate change must be accounted for in all future planning scenarios in order to adequately account for water use needs and hydrologic shifts.

Strong industrialization and growth patterns in major resource-intensive industries have contributed to the era of anthropogenic climate change. This has enacting major stress on natural cycles and human systems. Current levels of post-industrial warming have reached $1^{\circ} \mathrm{C}$ above average global temperatures, with the levels of $1.5^{\circ} \mathrm{C}$ and $2^{\circ} \mathrm{C}$ (as outlined in the Paris Agreement of 2015) both having significant, wide-reaching consequences for human-environment interaction. The UN Intergovernmental Panel on Climate Change, or IPCC, released analysis on the benefits of mitigating warming levels to $1.5^{\circ} \mathrm{C}$, published in October of 2018, and findings suggest that a significant difference to clean water supply, food security, health and safety, and environmental preservation exists at this relatively reduced level. In order to meet this aim, global net carbon emissions must be halved in comparison to 2010 levels by 2030 (IPCC 2018). Long-term effects will continue long after normalization of emissions and temperature. This is of particular concern for water going into the future, including both surface water and groundwater supplies.

Increasing global warming from climate change holds many different implications for water stresses in different regions. Trends from satellite remote sensing data and environmental measures reveal that groundwater stress is increasing in many key aquifers around the world, such as the Ganges-Brahmaputra Basin on the Indian subcontinent, the Arabian Aquifer System in the Middle East, and Central Valley Aquifer in California, the United States (Richey et al 2015). Water quantity is decreasing faster than the rate of natural repletion, particularly during drought conditions when groundwater is relied upon heavily by water-intensive industries such as agriculture. Many surface water supplies are vulnerable to changes in climatic conditions, as well. Increasing dry conditions, infrastructure development, and diversion rates in many parts of the world are increasing evaporative stresses on lakes and standing bodies of water and often lowering flow rates in rivers and tributaries. Flooding due to increased snowmelt is a certain eventuality in many regions lying in the immediate valleys of mountain systems. Furthermore, changes to water quality threaten remaining quantities of freshwater due to pollution, nutrification, invasive species, and saline intrusion. Carbon forcing is also projected to raise ocean acidification levels considerably. As such, sustainable water policy is imperative and must account for current and anticipated changes due to global warming.

The issue of water governance will be discussed at length in this study. Particularly, the authors seek to frame the issues of water stress and governance in 
the larger frameworks of sustainable development and water diplomacy. Sustainable development as a field of study acknowledges the complex interactions of environmental protection, economics, and human equity. Understanding of this context is integral to the discussion of water problems. The framework of water diplomacy acknowledges this as well by treating water systems at the watershed level; watersheds are large areas of lands (potentially the sizes of nations, regions, and/or states) that all drain water to a common outlet point. This physical designation recognizes water as a natural system independent of political constraints, while also allowing room for all stakeholders and political participants to take active roles in its upkeep and sustained management. Negotiations over water rights are commonplace, dating back largely to the 20th century, however, consideration of water system health and sustainable use are still new and developing fields and paradigms of thoughts. This thesis examines the nuances of this debate, as well as the importance of accurate data and joint-fact finding among water partners.

Preferred methods on policy development include advocacy for a strong basis in scientific research and analysis. Proponents for this view specify the tripartite, or a progression moving from science to policy to law for environmental and water issues (Percival 2017). Indeed, water networks represent unbounded problems and open systems rather than traditional closed systems engineering problems. Boundaries are dynamic and porous, this in addition to complexity resulting from the interaction of natural, societal, and political forces. Bridging the divide is two paradigms to be negotiated by decision-makers and typified by two scales: (1) Values vs. Facts (2) Scientists vs. Policy-makers. In this context, water management plans provide the basis for equitable water governance and baseline data on water flow and quality in watershed bains. Inherent uncertainty is to be accounted for by introducing adaptive management plans into governance design. Historic data can be aggregated from multiple sources including environmental sensors and remote sensing data.

Finally, Earth observing satellite missions have been active since the 1960s, with most early iterations simply pointing various cameras back at the planet. The field of remote sensing has developed rapidly since these early missions, and a sophisticated and abundant array of sensors and missions are currently orbiting the Earth, with projections of the number of missions expected to only increase in subsequent years. One reason for this is the advent of the "small satellite", which was not only smaller in size but also reflected a perspective shift towards more innovative, experimental satellite missions being launched. Increasingly, satellite constellation missions are being planned and launched so that a system of satellites is taking measurements in tandem. In addition, private satellite industry is growing though the scope for this study is mostly limited to NASA or governmental satellite missions (GRACE, SMAP, CYGNSS, SWOT, and LANDSAT). Satellite sensors vary widely: Central types include radar, microwave, or optical and active or passive. Design and type depends most heavily on the intended measurement variable or signal because electromagnetic and gravitational properties differ significantly. A plethora of satellite data currently exists, and much of it is publically available from agencies such as NASA and the European Space Agency (ESA). This thesis seeks to explore the current uses and scope of earth observation satellite data for water management, as well as investigate the expanded potential uses of it and the implications this has for sustainable water governance around the world.

\section{A. Sustainable Development}

The Triple Bottom Line 
Sustainable development encompasses a concern arising from evidence of strong environmental degradation, both despite and resulting from rapid economic growth and a "largely disappointing record" of development, including worsening poverty in some places (Kemp \& Parto 2005). Much sustainability literature constructs an understanding of sustainable development based on a number of interdependent pillars, often two (ecological and socioeconomic), three (ecological, social, economic) or five (ecological, social, economic, cultural, political) (Gibson 2001). The popularized Triple Bottom Line theory proposed in the mid-1990s is the idea that sustainable development is a feedback loop between three central mechanisms of environmental protection, economics, and equity (Slaper \& Hall 2011). Water system protection, under the broader category of environmental protection, is also important to consider in relation to the economic and human equity portions of the triple bottom line. For example, in dynamic environments, technological development trajectories are associated with inherent uncertainty whereby sustainable technology transition feasibility is dependent on sufficient innovation in industry and political systems (Sartorius 2004). This is correlated to the availability of sufficient capital and opportunity to fund research and innovation efforts. The success of such efforts would in turn benefit the surrounding communities and technological development could result is inventions towards cleaner water or reduced overall consumption, benefiting the immediate ecosystem. So the triple bottom line is important for framing the issue of sustainable water management within the larger, intertwined framework of environmental, economic, and equity issues, commonly referred to as the three 'E"s. The recognition of sustainable development as a holistic set of goals is the basis of research and management recommendations within the specific domain of water.

\section{United Nations SDGs}

In keeping with the ideals of the triple bottom line, the United Nations Sustainable Development Goals (UN-SDGs) were established as a set of 17 measurable targets and indicators designed to succeed the Millenium Development Goals (Ruhil 2015). They are aimed at promoting "peace and prosperity, for people and planet" both now and into the future. The SDGs incorporate the triple-bottom line concept by embracing a combination of economic development, environmental sustainability, and social inclusion goals. These goals were set out and agreed upon by almost every nation and represent a collective aim for a sustainable and equitable future. Goals include measures such as "No poverty", "Good Health and Well-being", "Clean Water and Sanitation", "Sustainable Cities and Communities", and "Climate Action". Broad in nature, the SDGs represent the similar holistic focus needed to address water stress in communities and ecosystems worldwide. Experts have suggested that substantial investment is needed to reach the major goals (poverty reduction, biodiversity conservation, climate change mitigation, and primary health) at about $2-3 \%$ of total global income (Sachs 2012). Among these priorities is the need to improve, protect, and renew water resources in order to advance public health, sustain communities, and ensure equitable opportunity for vulnerable and disadvantaged populations in particular.

In following, technology development and transfer remain major imperatives for low to middle-income economies, marking a transition from the traditional concentration of technology in high-income countries. Spirited debate still exists in the fields of economics, regional planning, and international development between the merits of technological transfer and technological learning. Here, technology transfer refers to the actions of a more "technically-advanced" organization to share 
technology with a less advanced organization. This would be like a high-income nation sharing sharing research from well-funded university research programs or government initiatives. Technological learning, however, seeks to understand how less technologically advanced organizations can develop capacity when working with more technicallyadvanced partners (Wood \& Weigel 2011). Proponents argue that this means leads to more sustainable solutions for involved parties because the recipients have access to source processes and the opportunity to build lasting expertise. Both means of technology development remain integral to the advancement of water resources in an equitable and sustainable manner; water is a boundaryless resource, and watershed level characteristics and health are paramount to regional political, cultural, and economic norms.

\section{Complex Systems}

Hydrological, climatic, and often economic systems are all considered to be complex systems. The defining characteristic of complex systems, and ecological systems in particular, is open-endedness or limited predictability of total system outcomes and tradeoffs (Rammel \& Bergh 2003). That is, complex systems are uncontrollable in the sense that small alterations and disturbances can and will have any infinite of unknowable consequences. The butterfly effect expresses the metaphor that the fluttering of the insect's wings on one side of the world can unknowingly cause a series of chain events leading to a hurricane or cyclone on another side of the world. This kind of phenomenon is also what makes water management a particular challenge and introduces a host of uncertainty. Interactions between individual system components called "components" or "agents" often lead to large scale emergent behaviors that are not easily predicted with knowledge of individual agents behaviors alone. Two dominant forms of interaction among agents are asymmetric (where agents play different, distinct roles) and symmetric interactions (where agents compete for common goals or resources) (Mitchell \& Newman 2002). General problems can also be classified in a number of ways, namely simple, complicated, complex, and "wicked" problems. Simple and complicated problems each have definite solutions and different levels of difficulty required to solve them. Complex problems have no definite solution, but rather many. However, "wicked" problems, of which water is an archetypal example, involve additional social or cultural dimensions that are typically impossible to "solve" outright (Islam \& Susskind 2013). Mainly, there is incomplete and often conflicting information, a large number of people or stakeholders involved, and a large economic component, all of which are connected and rely on each other. In this scenario, the focus is on iterative improvement rather than a one-time approach to solving water issues. Feedback learning mechanisms provide for adaptive management and built-in means of dealing with uncertainty. This component is vital to effective water agreements as large uncertainty grows as a reality for all complex and "wicked" problems.

\section{B. Global Climate Change}

\section{Importance of Climate Change in Water Governance}

Studies and sustainable management plans for future scenarios must take into account the effects of global climate change. Many in the water management community have come to raise concerns over the usefulness of historical statistics in designing water systems for an uncertain future (Stakhiv 2011). Utilizing probabilistic statistics is a standard method for determining estimates of future water trends and demands. However, in complex systems of water there exists too great of uncertainties to be able to predict future needs with confidence based on past records, particularly with the effects of climate change altering the hydrologic 
cycle significantly. For example, increasing severity of storms, additional snowmelt, and prolonged periods of drought are emergent properties associated with climate change. Scenario planning accounts for these future alternatives with a "portfolio"-based approach and forecast models (Islam \& Susskind 2013). This allows for focus on the future spectrum of potentialities and provides for resilient design and risk mitigation. Planning for water cannot undertaken without adequate attention to climate change effects and eventualities.

\section{The Paris Agreement}

The UN Paris Agreement of 2015 aims to hold global warming to a level well-below $2^{\circ} \mathrm{C}$ as compared to pre-industrial warming levels and further calls for efforts to limit warming to $1.5^{\circ} \mathrm{C}$ warming. It is a framework of the United Nations agreed upon by 195 signatory nations with individual national targets for greenhouse gas emissions reductions. Early evidence suggests that most nations will fall well short of their stated goals. Initial pledges submitted by party-nations would result in a projected global warming of $2.7^{\circ} \mathrm{C}$ above pre-industrial levels as stands, given the assumption that national pledges be fully-implemented (Falkner 2016). These successive five-year, nationally-determined contributions (NDCs) require parties to "represent a progression beyond the party's then current nationally-determined contribution", as stated in Article 4.3 of the Paris Agreement. The agreement takes the governance approach of "pledge and review" then subsequently "gauge and review" as opposed to setting strict, mandatory limits (Schleussner et al 2016). Here, governance is distinct from government because it is a range of administrative systems to manage water resources rather than a narrower perspective of centralized decision-making from a political entity. Better governance exhibits a strong casual relationship with vital outcomes such as improved water quality and sustainability, human health (eg. lower infant mortality), literacy rates, and quality of life (as indicated by relative per capita incomes) (Rogers \& Hall 2003). As a result of the Paris negotiations, the IPCC was requested to conducted further research into the benefits, effects, and limitations of the approach, in addition to identifying specific mitigation pathways.

\section{Limiting Climate Change to $1.5^{\circ} \mathrm{C}$ Warming}

Fulfilling requests by nations of the Paris Agreement, the UN Intergovernmental Panel on Climate Change (IPCC) in October of 2018 released a special report on the "impacts of global warming above $1.5^{\circ} \mathrm{C}$ ". The report drew special attention to the significant difference in outcomes of $1.5^{\circ} \mathrm{C}$ warming as compared to $2^{\circ} \mathrm{C}$ warming. Discussion of climate change and its impacts in this study will largely be discussed in this context of this comparison. As effects to the water cycle at not isolated, the discussion of climate change effects is broad to demonstrate the complex reactions and feedbacks of Earth's many systems when faced with the disturbance of excessive anthropogenic greenhouse gas emissions. In addition, the human cost of global warming is strongly tied to mitigation pathways with vulnerable and disadvantaged communities again being most at risk to harm. At present, human activities since pre-industrial times are likely to have already caused $1^{\circ} \mathrm{C}\left(0.8^{\circ} \mathrm{C}\right.$ to $1.2^{\circ} \mathrm{C}$, high confidence) of warming - some scientists do suggest that warming rates are higher than projected. At current trends, warming is likely to reach $1.5^{\circ} \mathrm{C}$ between 2030 and 2052 . Anthropogenic emissions to present (including greenhouse gases, aerosols, and precursors) alone are unlikely to cause further warming of more than $0.5^{\circ} \mathrm{C}$ on a decadal or century time scale (IPCC 2018). However, reaching and sustaining a level of net-zero global, anthropogenic $\mathrm{CO} 2$ emissions is essential to limiting and inducing global anthropogenic warming stabilization or decline. The maximum level of warming would depend on the 
time required to reach net-zero $\mathrm{CO} 2$ emissions and the level of net non-CO2 radiative forcing in the years prior to maximum temperature.

Climate-related risks for natural and human systems are significantly higher at $2^{\circ} \mathrm{C}$ warming and relatively lower at $1.5^{\circ} \mathrm{C}$, though still severe. Increases in mean temperature across most land and oceans are projected, with extreme hot days in mid-latitudes warmer by $3^{\circ} \mathrm{C}$ to $4^{\circ} \mathrm{C}$ between each global warming scenario $\left(1.5^{\circ} \mathrm{C}\right.$ global warming and $2^{\circ} \mathrm{C}$ global warming, respectively) and extreme cold nights in high latitudes warm by $4.5^{\circ} \mathrm{C}$ to $6^{\circ} \mathrm{C}$ at each scenario. Risk from drought and low amounts of precipitation in some regions is projected to be higher at $2^{\circ} \mathrm{C}$ than $1.5^{\circ} \mathrm{C}$, and risk from heavy precipitation events in many high-latitude or high-elevation regions in the northern hemisphere (eastern Asia and eastern North America) is also projected to increase. In addition, high precipitation that is associated with hurricanes or cyclones is projected to be higher at $2^{\circ} \mathrm{C}$ than $1.5^{\circ} \mathrm{C}$ at global scale, as is total aggregated heavy precipitation. This results in a high confidence that increased global land area that will be affected by flood hazards at $2^{\circ} \mathrm{C}$ compared to $1.5^{\circ} \mathrm{C}$ warming. Sea level rise models project a range of 0.26 to $0.77 \mathrm{~m}$ rise (relative to 2005 ) by 2100 for $1.5^{\circ} \mathrm{C}$ of warming and $0.1 \mathrm{~m}(0.04-0.16 \mathrm{~m})$ higher for $2^{\circ} \mathrm{C}$. The IPCC estimates that this sea level rise mitigation implies that 10 million fewer people (based on 2010 population) would be exposed to related risks, assuming no adaptation. This does not take into account ice sheet instabilities in Antarctica or irreversible losses in the Greenland ice sheet that each could result in multi-meter rise on a century or millennial time scale and could be triggered at $1.5^{\circ} \mathrm{C}$ to $2^{\circ} \mathrm{C}$ warming. Sea level rise will continue beyond 2100 even if global warming is limited to $1.5^{\circ} \mathrm{C}$ in the 21 st century. The slower rate of sea level rise at $1.5^{\circ} \mathrm{C}$ reduces the risks of increased saltwater intrusion, flooding, and damage to infrastructure, as well as limits the exposure of small islands, low-lying coastal areas, and deltas to these risks.

Ecosystem risks, including impacts on biodiversity, species loss, and extinction, are projected to be lower at $1.5^{\circ} \mathrm{C}$ than $2^{\circ} \mathrm{C}$. Furthermore, limiting warming is projected to lower the climate change impacts on terrestrial, freshwater and coastal ecosystems on which humans rely. At $2^{\circ} \mathrm{C}$, approximately $13 \%$ of terrestrial land area is projected to undergo a transformation of ecosystem, whereas risk is $50 \%$ lower at $1.5^{\circ} \mathrm{C}$ warming. Among the most at-risk ecosystems or biomes are high-latitude tundra and boreal forests, where woodland shrubs are already encroaching, and thawing of permafrost can be limited by a magnitude of 1.5 million $\mathrm{km} 2$ to 2.5 million $\mathrm{km} 2$ by limiting global warming to $1.5^{\circ} \mathrm{C}$ rather than $2^{\circ} \mathrm{C}$. Despite feedback mechanisms that may offset some effects of thawing permafrost, the loss of $\mathrm{CO} 2$ to the atmosphere is likely to be a substantial source (Schuur et al 2008). At $1.5^{\circ} \mathrm{C}$ warming, one summer without sea-icec in the Arctic is projected per century, whereas the frequency increases to once per decade at $2^{\circ} \mathrm{C}$ warming. Changing ocean composition properties associated with higher temperatures and increased global $\mathrm{CO} 2$ emissions, including ocean acidification and decreased oxygen levels, are higher at $2^{\circ} \mathrm{C}$ warming than $1.5^{\circ} \mathrm{C}$ warming. This affects marine specifies, for example, and coral reefs are projected to decline $70 \%-90 \%$ are $1.5^{\circ} \mathrm{C}$ and greater than $99 \%$ at $2^{\circ} \mathrm{C}$ warming. The risk of irreversible loss to many marine habitats and ecosystems increases with global warming, especially at levels at or exceeding $2^{\circ} \mathrm{C}$.

Populations at greater risk (health, livelihoods, food security, water supply, human security, and economic growth) at $1.5^{\circ} \mathrm{C}$ and beyond include disadvantaged and vulnerable populations, some indigenous peoples, and local agriculture or coastal-dependent communities. Lower risks are 


\section{Breakdown of contributions to global net $\mathrm{CO}_{2}$ emissions in four illustrative model pathways}

Fossil fuel and industry AFOLU BECCS

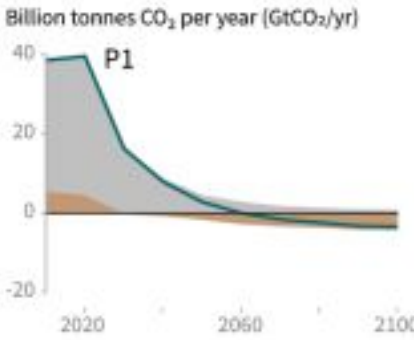

P1: A scenario in which social, business and technological innovations result in lower energy demand up to 2050 while living standards rise, especially in the global South. A downsized energy system enables rapid decarbonization of energy supplyAfforestation is the only CDR option considered; neither fossil fuets with CCS nor BECCS are used.

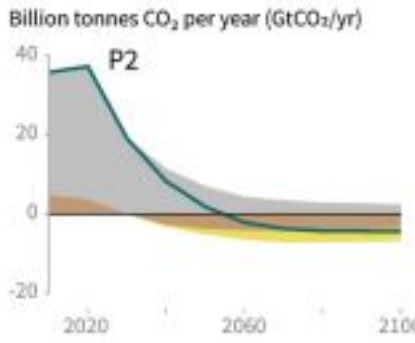

P2: A scenario with a broad focus on sustainability including energy intensity, human development, economic comvergence and international cooperation, as well as shifts towards sustainable and heslthy consumption patterns, low-carbon technology innovation, and well-managed land systems with limited societal acceptability for BECCS.

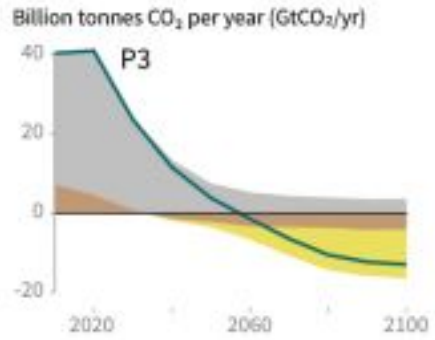

P3: A middle-of-the-road scenario in which societal as well as technological development follows historical patterns. Emissions reductions are mainly achieved by changing the way in which energy and products are produced, and to a lesser degree by reductions in demand.
Billion tonnes $\mathrm{CO}_{2}$ per year ( $\mathrm{G}+\mathrm{CO}_{2} / \mathrm{yr}$ )

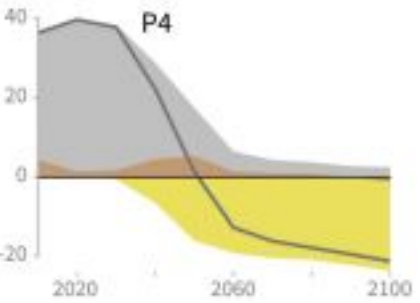

P4: A resource- and energy-intensive scenario in which economic growth and glabalization lead to widespread adoption of greenhouse-gas-intensive lifestyles, including high demand for transportation fuels and livestock products. Emissions reductions are mainly achieved through technological means, making strong use of CDR through the deployment of BECCS.

\begin{tabular}{|c|c|c|}
\hline Global indicators & P1 & $\mathrm{P} 2$ \\
\hline Pothwoy ciossification & No or limited overshoot & No or limitedo \\
\hline COs enission change in 2030 ( 96 rel to 2010 ) & -58 & -47 \\
\hline Lin 2050 ( $96 \mathrm{rel}$ to 2010 ) & -93 & -95 \\
\hline Fyoto-GHG emissians ${ }^{*}$ in 2030 (\% rel to 2010 ) & -50 & -49 \\
\hline Lin 2050 ( $\%$ rel to 2010) & -82 & .89 \\
\hline Finol energy demand ${ }^{* t}$ in 2030 ( $\%$ rel to 2010) & -15 & -5 \\
\hline Lin 2050 ( 96 rel to 2010) & -32 & 2 \\
\hline Renewable share in electricity in 2030 (96) & 60 & 58 \\
\hline Lin 2050 (\%) & 77 & 81 \\
\hline Primary energy from coal in 2030 (\% rel to 2010) & -78 & -61 \\
\hline 4 in 2050 ( $(\%$ rel to 2010 ) & -97 & -77 \\
\hline from oil in 2030 ( $1 \%$ ref to 2010) & -37 & -13 \\
\hline 4 in 2050 ( 16 rel to 2010) & -87 & -50 \\
\hline from gas in 2030 ( 96 rel to 2010 ) & -25 & -20 \\
\hline 4 in 2050 ( 96 rel to 2010) & -74 & -53 \\
\hline from nuclear in 2030 ( $\%$ rel to 2010) & 59 & 83 \\
\hline 4 in 2050 (\$s rel to 2010) & 150 & 98 \\
\hline fram biomess in 2030 ( 96 rel to 2010 ) & -11 & 0 \\
\hline 4 in 2050 (\$s rel to 2010) & -16 & 49 \\
\hline from nan-biomass renewables in 2030 ( 96 rel to 2010 ) & 430 & 470 \\
\hline 4 in 2050 (196rel to 2010) & 833 & 1327 \\
\hline Cumulative CCS untii 2100 (GtCOs) & 0 & 348 \\
\hline Lof which BECCS $\left(\mathrm{GrCO}_{2}\right)$ & 0 & 151 \\
\hline Land area of bioenergy crops in 2050 (million $\mathrm{km}^{2}$ ) & 0.2 & 0.9 \\
\hline Agricuiturai $\mathrm{CH}_{4}$ emissions in 2030 (\% rel to 2010) & -24 & -48 \\
\hline in 2050 (16 rel to 2010) & -33 & -69 \\
\hline Agricultural N>O emissians in 2030 ( 96 rel to 2010) & 5 & -26 \\
\hline in 2050 (\% rel to 2010 ) & 6 & -26 \\
\hline
\end{tabular}

NOTE: Indicators have been sefected to show global trends identified by the Chapter 2 assessment. Notianal and sectorol charocteristics can differ substantialify from the giabol trends shown above.

\begin{tabular}{l|l} 
P3 & P4 \\
\hline
\end{tabular}

4

\begin{tabular}{l|}
-41 \\
-91 \\
-35
\end{tabular}

\begin{tabular}{l|l}
-95 \\
49
\end{tabular}

\begin{tabular}{r|r}
-99 \\
-78
\end{tabular}

$-517$

\begin{tabular}{l|l}
2 & \\
58 &
\end{tabular}

$81 \quad 63$

$\begin{array}{ll}-61 & -75 \\ -77\end{array}$

\begin{tabular}{l|l}
-77 & -73
\end{tabular}

\begin{tabular}{l|l}
-13 & -3
\end{tabular}

$\begin{array}{ll}-50 & -81 \\ -20 & -33\end{array}$

\begin{tabular}{r|r}
-20 & 33
\end{tabular}

\begin{tabular}{l|l}
-53 & 21
\end{tabular}

83

98

49

1327

348

151
0.9

$-48$

$-69$

$-26$

$-26$

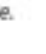

Figure 1: Climate Change $1.5^{\circ} \mathrm{C}$ Mitigation Models

(Source: IPCC (IPCC 2018)) 
projected for heat-related mortality at $1.5^{\circ} \mathrm{C}$ warming than $2^{\circ} \mathrm{C}$ warming, including the effects of urban heat islands, and risks from some vector-borne diseases such as malaria and dengue fever are projected to increase with warming $1.5^{\circ} \mathrm{C}$ to $2^{\circ} \mathrm{C}$ and to change in geographic range. Reductions in potential food availability due to smaller net yields of crops such as maize, rice, and wheat are projected to be larger at $2^{\circ} \mathrm{C}$ warming than $1.5^{\circ} \mathrm{C}$ warming. Moreover, limiting warming to $1.5^{\circ} \mathrm{C}$ compared to $2^{\circ} \mathrm{C}$ may also reduce the portion of the population exposed to water stress by up to $50 \%$ (considerable variability between regions). Due to changes in aridity when warming is limited to $1.5^{\circ} \mathrm{C}$ as compared to $2^{\circ} \mathrm{C}$ warming, small island developing states could experience lower water stress. Countries in the tropics and Southern Hemisphere tropics are projected to experience the highest impact to economic growth due to climate change, exasperated at $2^{\circ} \mathrm{C}$ as compared to $1.5^{\circ} \mathrm{C}$ warming, and also, compounding risks from areas across energy, food, and water sectors have the potential to overlap and create new risks, hazards, and vulnerabilities. In addition, greater proportions of people will be exposed and susceptible to poverty and multiple climate-related risks in Africa and Asia (high confidence) and more than a $60 \%$ chance that the global benefits would exceed US\$20 trillion under a 3\% discount rate to 2010 US dollars at $1.5^{\circ} \mathrm{C}$ warming (Burke et al 2018).

Four illustrative model pathways (See Figure 1) show mitigation strategies required to achieve enough net emissions reduction to limit warming to $1.5^{\circ} \mathrm{C}$ with no or limited overshoot. In model pathways that limit warming to $1.5{ }^{\circ} \mathrm{C}$, global net anthropogenic $\mathrm{CO} 2$ emissions are to decline by about $45 \%$ from 2010 levels by 2030 to reach net zero emissions around 2050. Pathways also involve deep reductions in methane and black carbon (soot) by $35 \%$ or more by 2050 relative to 2010 . Utilizing climate models AR5 and GMST based on global mean surface temperature and air temperature, estimates of remaining carbon budget range from $420-770$ GtCO2 and $50 \%-66 \%$ probability of limiting warming to $1.5^{\circ} \mathrm{C}$. All mitigation pathways use Carbon Dioxide Removal (CDR) in varying amounts. Mitigation scenarios (P1, P2, P3, P4) range from lower energy demand and rising standards of living especially in the global South to societal and technological development following historical patterns, as well as a resource- and energy- intensive scenario heavily-dependent on CDR. Consistently in all mitigation scenarios limiting global warming to $1.5^{\circ} \mathrm{C}$, a strong decline in energy share from fossil fuel, particularly coal, is required (59\% to $78 \%$ decline by 2030 ). For mitigation, the share of renewable energy in electricity is projected to increase in the interquartile range of $47 \%$ to $65 \%$ increase by 2030 . Agricultural methane emissions are also projected primarily to decrease by an interquartile range of $24 \%$ to $47 \%$ in all but higher overshoot scenarios (IPCC 2018).

\section{Framework for Water Diplomacy}

\section{Need for Holistic Water Management}

Traditional water management principles apply systems thinking approaches, whereby "reductionist" frameworks are prioritized. In a historical look, water management has progressed through many phases, the first being community management by early peoples living directly adjacent to waterbodies in early centuries. Around the early 1900s and prior, water management shifted to regional management patterns with basin management being introduced to deal with water quantity, in particular. National water management policies were introduced in response to public outrage in the United States notably in the 1970s and beyond with the founding of the US EPA and the passage of a slew of environmental regulations including the Clean Water Act and the Safe Drinking Water Act. This era of water governance addresses 
integrated and multi-functional uses of water, for example "fishable" and "swimmable" waters, at the river basin level and featuring institutional cooperation across scales (national, state, local, and stakeholder). The US EPA leaves enforcement to each of the state environmental agencies, and cities, companies, and residents are expected to comply with these policies and laws.

Current paradigms have moved more towards recognizing water networks as complex systems and shifting from viewing water as a scarce resource. Holistic water management spans a broad range of water issues. For example, the definition of water is broadened. Blue water sources (i.e. lakes, streams, and aquifers) and green water sources (i.e soil moisture) - and distinctions between them - can significantly change the availability or recording of water resources (Falkenmark and Rockstrom 2006). Embedded or virtual water, which is water used in the production of goods around the world, also has a large influence on the introduction, maintenance, or potential reversal of water stress in many areas of world. The definitions of water are means of expanding resources and introducing holistic, basin-level management. Phrasing and agreeance on methods is therefore critical to sustainable water management. Water diplomacy addresses the need for best management practices in water negotiation, agreement, and management, especially in the nuance of terms and water systems health.

\section{Water Diplomacy}

The framework of water diplomacy recognizes the growing importance of water negotiations between multiple parties and at different scales of governance. Introduced by Professors Shafiqul Islam and Lawrence E. Susskind, water diplomacy outlines a negotiated approach to managing water and water networks, specifically in regards to watershed management and transboundary water management. Experts argue that the watershed, also called the problem-shed or policy-shed, level is the most efficient level of management because the river or watershed system must be jointly-managed by each of the nations or states that it traverses. The priority remains the equitable apportionment of water to satisfy respective needs while maintaining and restoring the health of the river system itself (Islam \& Susskind 2013). Many have suggested introducing negotiating parties of behalf of water systems themselves. This is a novel concept and critically acknowledges the central importance of sustainable water management for the benefit of ecosystem protection and renewal. Often this takes the form of nongovernmental organizations or advocacy groups partaking in negotiations that feature mainly other political factions like states or countries or user representatives like stakeholders or lobbying firms. In this manner, the needs of the watershed are voiced integrally in the negotiation process.

Joint fact-finding and knowledge sharing in particular are critical to integrate from the earliest possible point in negotiated water governance. The likelihood of subsequent agreement is substantially higher when compared to instances where all involved parties collect individual data. Water management plans - collected water resource data, reporting, and governance plans - often serve as the basis or starting point of water negotiations or diplomacy. Remote sensing is a critical component of this effort. Earth observations can establish regional patterns, and reach high enough spatial resolutions in many cases to apply to water data on the order of tenths of a meter to the tens of meters in magnitude. This is high enough resolution to track individual rivers and tributaries, surface water lakes and reservoirs, and changes in groundwater water masses. The availability of this data in processed and readily comprehensible forms contributes significantly to the decision making capacity of stakeholders and institutions. It is important to 
consider scale of management in the implementation of water diplomacy, as well.

\section{Intrastate Water Management}

At the scale of state or sub-regional water governance, management is often focused on in-stream flows, water quality, surface water, and groundwater resources. Large variability exists in the scope, regulatory control, and management measures of different governing systems. Conjunctive management is one paradigm whereby surface and groundwater is managed jointly, reflecting the mechanics of the natural system. Here, groundwater is used to complement surface water shortages and build robust capacity to deal with climate change effects on water systems (Zhang 2015). Pilot projects exist in the Southeast United States, particularly New Mexico where adaptive management measures allow for the switching of surface and groundwater municipal supplies during dry and wet conditions (Collins et al 2012). With increased severity of droughts predicted in many areas due to climate change, adaptive management techniques are increasing in importance. Other methods of water management focus on private water rights in priority over collective water management. Texas exercises the rule of capture, allocating uncapped groundwater rights to private property owners whose land covers portions of underground aquifers. Of the 17 million acre-feet of water use in Texas annually, approximately $80 \%$, or 10.2 million acre-feet, is groundwater. Here, no permitting is necessary except in select common law cases where "waste, malicious drainage, or negligent subsidence" are apparent. Tribal water rights are outlined in the Winters and Caliente Doctrines with regards to surface and groundwater, respectively. Management strategies vary widely across these scales, which in turn heightens the need for basin-wide water management and sustainable water governance to prioritize water system health.

\section{Interstate Water Management}

Three main methods for interstate water agreement exist relative to the United States context. In the first, state water plans are devised by each state government's environmental agencies and state legislatures. This is referred to as equitable apportionment, which is not necessarily equal in the legal notion. Kansas v. Colorado (1907) established the doctrine of equitable allocation in an original jurisdiction case over the transboundary allocation of the Arkansas River. It is applicable to resolving interstate disputes over water rights that originate in the Supreme Court as the "trial court" and largely implement the principles adopted by each state as a means of third-party arbitration.

Interstate compacts are agreements between two or more states over water rights, which Congress approves. These contracts represent agreements on policy issues and are among the strongest management mechanisms for adaptive water governance among states. On average, a state today belongs to approximately 25 interstate compacts, particularly (1) advisory compacts which create study commissions and (2) regulatory compacts which create administrative agencies.

Through congressional appropriation, the US Congress divides water among party states and entities. Most water resources east of the Mississippi River were apportioned according to this federal discretion. The foundational water case of Arizona v. California (1963) recognized the Commerce Power in relation to the Lower Colorado River Basin's 7.5 million acre-feet (4.4 MAF allocated to California annually and 2.8 MAF to Arizona annually). This established precedent for Congressional authority to appropriate water, as an extension of its ability to regulate other forms of interstate interaction and commerce. 


\section{International Water Management}

Often, there exists a mismatch between political and hydrological boundaries, as is many times the case between adjacent nations (Norman et al 2012). The UN Convention on the Non-Navigational Uses of Water is the seminal international agreement on water diplomacy and transboundary water management. Initially agreed upon in 1997, the convention was ratified by over forty nations and entered into force in 2014. Several key articles establish principles central to water diplomacy. Article 5 stipulates equitable and reasonable utilization by all watershed partners, and Article 7 further addresses the priority of preventing harm to watershed partners through thorough consideration of capital project tradeoffs (G.A. Res 1997). Implementation of this is aided by the timely notification cause of Article 12, as is mirrored in the water diplomacy framework.

\section{Negotiation Theory}

Water diplomacy is foundationally grounded in the assertion that water governance is a non-zero sum endeavor rather than a zero sum one. Non-zero sum implies that value can be created by participants in water governance such that the benefits of health ecosystem management are not strict and limited. This means that water should not be viewed simply as an entity to divide and allocate between parties. Instead, water is to be viewed as a dynamics, regenerative system that actually increases its utility when managed sustainably and equitably. In such a negotiation framework, the focus is shifted from scoring positional victories over perceived opponents towards a focus on the vested interests of respective parties. As outlined by scholars of negotiation, this focus on interests and is a largely effective tool to explore opportunities for agreement (Fisher et al 2011). In water management, parties each have an underlying interest in the sustainable health of water systems in their proximity. Following this inference, mutual gains approach is an empirically-based process that focuses on following independent standards, pursuing value creation, and understanding follow through (Friedman 1992). In the context of water governance, independent standards are founded in science and help translate to effective policy and law. Particularly, water management plans report on critical variables such as historical flows, climatic variation, and water quality measurements. Global water data is strongly bolstered by the integration of remote sensing data at regional and basin-wide scales. Abundant historical records also tend to strengthen negotiating positions for the respective parties.

In acknowledging relative positions, hydro -hegemons are negotiating parties, particularly Nation-states, which exercise disproportionate power over a waterbody, as is often exemplified by classic "upstream" nations. As popular convention says, possession is approximately 9/10th of the law. The Nile RIver Basin has experienced cycles of hydro-hegemony from downstream nations holding veto power over the actions of their approximately dozen upstream watershed neighbors. From the period of British colonial rule in Egypt, the nation has largely wielded hegemonic power shared with Sudan over the development of water resource projects including hydropower and diversion of water supply. Recent shifts power dynamics have been marked with the building of the Grand Ethiopian Renaissance Dam on the Blue Nile and negotiation procedures by the Nile Basin Initiative, which is an intergovernmental partnership of 10 upstream basin countries (Rahman 2018). Further, hydro-hegemony defined much of 19th and 20th century water management. The United States for example sponsored the Harmon Doctrine in relation to their water policy, stating that a country is "absolutely sovereign" over the segment of an international waterbody within its borders without exception (McCaffery 1996). Though allegedly never 
followed in practice later, it was shaped under the vision of US Attorney General Judson Harmon in the late 19th century over conflict with Mexico regarding use of the Rio Grande River. Similarly, it is important to consider dichotomy of positions in negotiations with regards to water.

The one-text negotiation method, or 'single negotiating text', lies at the convergence of these two concerns of exploring joint interests and considering relative negotiating power. The method introduces a third-party intervener, as was done at the Camp David Peace Negotiations in 1972, in order to focus interests of both parties towards jointly developing one single solution text. The UN Convention on the Non-Navigational Uses of Water also includes the provision of agreed-upon third-party interveners during instances of water conflict.This approach aids in reducing the impact of "positional bargaining" where negotiating parties are attached to stated ultimatums rather than true underlying interests and increases the likelihood of final agreement. Here, it is significantly more productive to focus on creating value for each party which also helps detangle negotiations from rigid norms and positioning.

\section{Triggering Mechanisms}

It is important in considering water diplomacy to also investigate the causes of broader public action or concern in water issues. The concept of triggering mechanisms is derived from the field of political science and is used to catapult once-private matters into the public forum of discussion (Gerston 2010). Either natural causes or marketed causes can serve as triggering mechanisms, and both or a combination of both are common with regard to water issues. Marketing causes refers specifically to the framing of public discussion and associated evocative meanings of terms, such as environmental protection versus environmental justice. Connotation of the later implies stronger legitimacy and urgency and a central element of importance to human life. This means of framing can be criticism to evoking action or concern in a general sense, as well as attracting immediate attention to important topics for political expediency.

A prominent example of severe water stress is the 2018 "Day Zero" situation of Cape Town, South Africa, in which Cape Town was in danger of becoming the first major city in the world to run out of water. According to the Cape Town disaster plan, when levels dropped to $13.5 \%$, water was to be cut off to the city, excluding only hospitals and informal settlements (Maxmen 2018). Drought, quite often a triggering mechanism for water issues, extended into a third year across the southwest region of South Africa as reservoirs drained faster than expected. Emergency procedures for the 4 million resident included water allotments to be collected at 200 distribution points with prioritization for medical services and informal settlements. Difficulty exists in allocating funds for proactive management, as well as high level direction, funding, and support. The point of no return, as dubbed "Day Zero", was a strongly effective tool for garnering public concern and action as the water situation reached critical crisis levels. This framing quickly brought the attention of the international community and drove action from local residents because the term "Day Zero" is widely understood and carries an alarming quality. Similarly, chronic water shortages exist in the Colorado River Basin, corresponding with drought cycles in the climatically arid region. Exacerbated by the allocation to seven surrounding states during a significantly wet climate period of record and independent state water management. The water crisis term of "deadpool" level was outlined to typify dire water reserves. This terming helped elevate the status of Colorado River water stress from technical crisis to a general public crisis. Thus, understanding of public and political action triggers is central to the practice of water diplomacy. 


\section{Remote Sensing Missions}

\section{Overview}

In a scientifically-oriented water policy and law approach, water data is essential and earth observing satellite remote sensing have provided unprecedented access to global data. Space-based monitoring coupled with on-the-ground observation is crucial for tracking changes on large scales - in natural-resource availability, landscape patterns and management, and social structure. In order to enhance this effort significantly, government investments need to be maintained or increased (Lu et al 2015). Remote sensing is critical to the environmental monitoring of Earth's complex systems, both of environmental and human systems as well as their interactions.

Satellite data provides holistic, recurrent, and normalized data over an extended period of time or orbit. From the 2007 report of the National Academy of Sciences (Chapter 3), it is widely acknowledged that satellite data have the potential to influence decisions addressing "health, agricultural, and environmental change problems" (National Research Council 2007). Remote sensing data could influence many issues affecting sustainability and the world's most disadvantaged populations. The various political, economic, and institutional settings around the world also define the framework in which remote sensing data can be utilized.

An example of a broadly successful platform for satellite remote sensing data integrated with human-environmental monitoring is the Famine Early Warning System Network (FEWS NET). Due to the effects of global warming, many populations that depend on subsistence farming are at risk of devastation and hunger throughout the world. Early identification ability is dependent on access to remote sensing data such as rainfall and climate monitoring and geographic data such as road networks and population concentration. Satellite rainfall estimates provided by CHIRPS (Climate Hazard Group InfraRed Precipitation Satellite) are vital in filling in gaps in grounded weather station observations, and also serve as inputs to model simulating drought severity and agricultural water balance (Verdin et al 2005). Effective solutions to such complex problems as famine risk take require taking into consideration natural factors and human factors like distribution of food, impact of war, and respective government capacities. The information provided by FEWS NET is then utilized and consistently revised by the co-operative management efforts of US government agencies along with 22 international field offices, national government ministries, international agencies, and NGOs. The partnership is effective in targeting complex problems because of its holistic partnership, adaptive management strategy, and successful utilization of satellite remote sensing resources for continual, near-real time climate and water information.

Historically, satellite remote sensing missions have been active since the 1960s and progressed significantly in number and capabilities. In the present era, small satellite innovation is strongly emerging and developing into a multibillion dollar industry. This era of abundant information holds innumerable potential for application to the most pervasive problems of climate change and water stress, including agricultural monitoring, tracking of environmental pollutants, changes in resourceintensive industries and energy providers, and risk of severe weather events such as hurricanes, floods, and wildfires. Authors of this study propose that many of these complex problems can be addressed and aided in large part by the utilization of remote sensing resources for water. Described in this section are five key satellite remote sensing missions for the study of water and adjacent issues - 
Landsat, GRACE, SMAP, CYGNSS, and SWOT. Discussion includes an overview of each mission's purpose and measurement scope, as well as current applications of the technologies in scientific and policy senses. In addition, means of accessing these data are addressed, as a main factor in the use of remote sensing data remains the ease of access and understanding of outputs for the average user. Open access is available to all NASA earth observing data via the Earthdata portal, however, post-processing resources are typically required. As such, integrated cloud-computing is often required to process and display large amounts of remote sensing data over various areas and timescales.

\section{LANDSAT}

The Landsat missions are among the longest-standing , continuous earth observing satellite missions in orbit. Recent USGS assessments found that the series of Landsat missions (starting from Landsat 1 in 1972) are among the most important satellite missions ever launched, including GPS and weather (Serbina \& Miller 2014). Landsat 8 was launched in 2013, and the system is radar, multi-spectral optical surveying at 30-meter pixel resolution with a 16 day revisit time. Landsat satellite images are useful in observing changes in water over time (See Figure 2). Multispectral images contain several different bands of light on the electromagnetic spectrum ranging from visible light as is seen by humans (Red, Green, and Blue bands) to the near-infrared, short-wave infrared, and thermal ranges. Each band and combinations of bands can be employed to identify different features of the earth surface and atmosphere below, and this is largely based on the spectral signatures, or reflectance and radiance, of the target features below. For example, cirrus clouds can be identified in band 9 of Landsat 8 $(1.375 \mu \mathrm{m}$ absorbance and radiance for water vapor in cirrus clouds), and vegetation is identifiable by its general reflectance of the near infrared spectrum and absorbance of red visible light (Xu et al 2014). This information can be used to identify several useful items such as agricultural yield, the presence of invasive plants, and the extent of surface water during different times of year. One tool that simplifies the processing of this data is the Climate Engine (developed through White House Climate Initiative by partnership of University of Idaho, Google, and the Desert Research Institute). By employing Google Earth Engine's vast processing power, the Climate Engine succeeds in the purpose of providing near-real time remote sensing products to any broad range of users, combining data from Landsat with scenes from other satellite missions such as MODIS and CHIRPS (Huntington et al 2017).
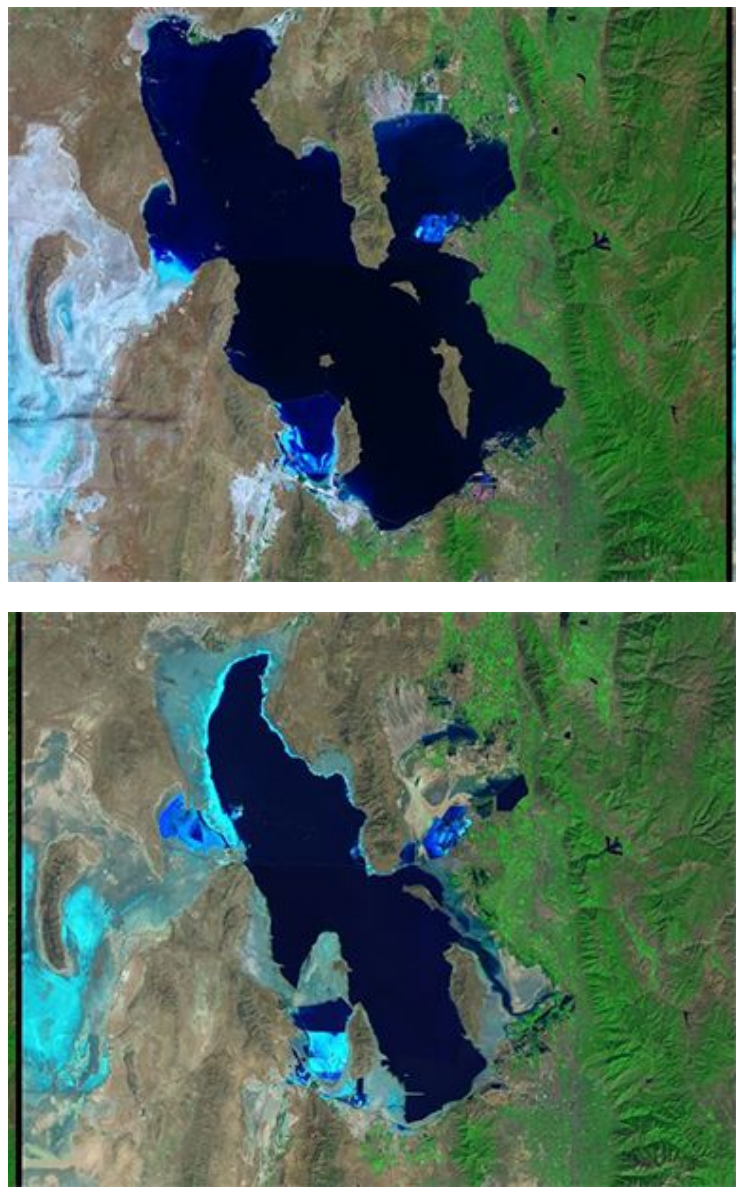

Figure 2: Landsat satellite images of the Great Salt Lake 1985 (above) and 2010 (below). (Source: USGS (Serbina \& Miller 2014)) 
Another tool is the Global Surface Water Explorer (developed by the European Commission Joint Research Centre) is made up of Landsat satellite scenes collected between 1984 and 2015 to produce a set of global water maps at 30-meter pixel solution. This tool allows users to survey an approximately three decadal span of water extents in different regions of the world. Studies show significant change in surface waterbodies over this time period with nearly $180,000 \mathrm{~km}^{\wedge} 2$ of new permanent surface water forming in some parts of the planet and almost $90,000 \mathrm{~km}^{\wedge} 2$ of permanent waterbodies disappearing from other places (Pekel et al. 2016). This shift is closely linked to climate change as follows: Increases associated with reservoirs and accelerated snow and glacier melt (particularly in Tibet) and losses associated with drought and infrastructure such as river diversion, damming and unregulated water use (mainly in Kazakhstan, Uzbekistan, Iran, Afghanistan and Iraq). The data is critical in monitoring water changes due to climate change and human activity, as well as broadening public access to satellite remote sensing data. Integrating higher resolution imagery from radar and optical satellite imagery from ESA-Sentinel 1 and 2 (each 10-meter pixel resolution) will lead to improved functionality and utility of the system. In addition, combination with further datasets could add to estimates of total water discharge and sea level rise worldwide; have applications to risk, resilience, and infrastructure planning with regards to water; and help verify commitments to multilateral environmental agreements. Dark blue areas represent permanent water and the lighter blue areas represent seasonal water. In addition, green colors are areas of new seasonal water and pink colors are areas of disappearing seasonal water (See Figure 3).

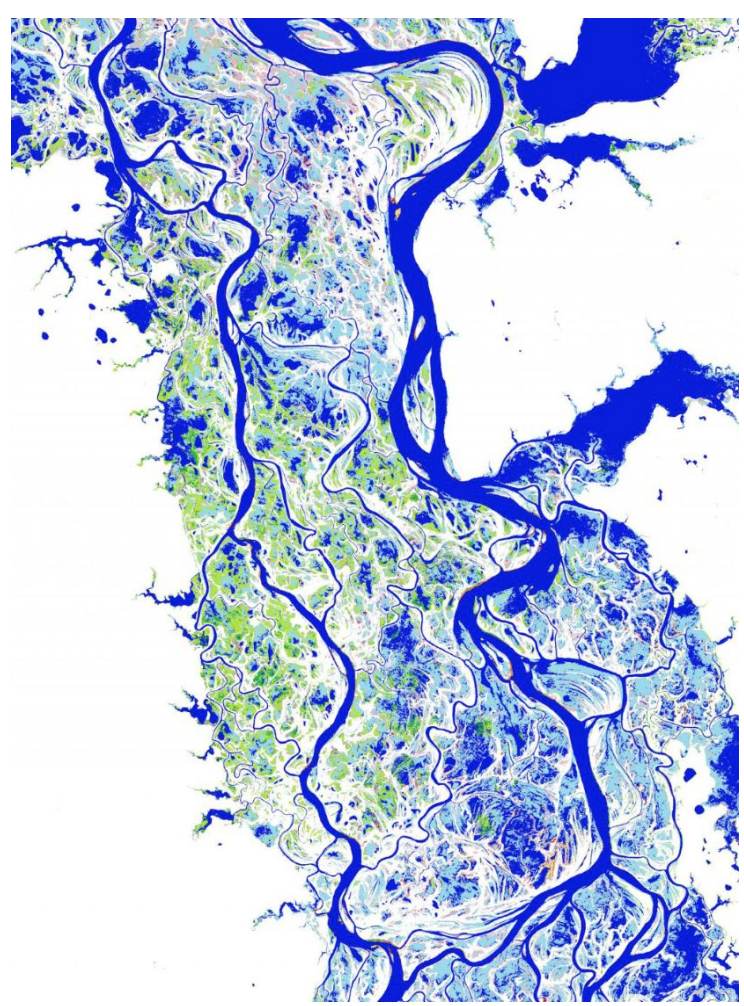

Figure 3: Global Surface Water Explorer map of the River Ob (Река Обь) in western Siberia, Russia. (Source: European Commission - Joint Research Center (Pekel et al 2016))

\section{GRACE}

NASA's GRACE mission are a pair of twin satellite modules launched in 2002 and orbiting in synchronous, staggered flight paths. The satellites measure changes in relative proximity between themselves at an accuracy 1/25,000th of an inch accountable to changes in mass (gravitational field) on Earth. Measurements are filtered for noise using temporal mean to remove gravity anomalies and derive water measurements in changes of surface water, ground water, ice, snowmelt, and soil moisture storage. Compared with independent water storage estimates from water balance for regions $(\mathrm{dS} / \mathrm{dt}=\mathrm{P}-\mathrm{E}-\mathrm{Q})$, or total water change by account of precipitation, evapotranspiration, and streamflow, GRACE measurements perform with good accuracy in determining water storage changes (Richey et al 2015). The data from these satellites has been critical in providing detailed information on the rates 
of global groundwater depletion, in particular. Groundwater stress further is compounded by a number of factors such as salinization, contamination, changing climate, and increased population growth.

Analysis GRACE satellite data in California over the 78 month-period from October 2003 to March 2010 revealed severe water storage changes in the Sacramento and San Joaquin River Basins. The basins lost water at a rate of 31.0 plus/minus 2.7 $\mathrm{mm} / \mathrm{yr}$ of equivalent water height, or $30.9 \mathrm{~km}$ cubed in volume over the selected time period. Of this, the Central Valley (see map) accounted for 20.4 plus/minus $3.9 \mathrm{~mm} / \mathrm{yr}$ of groundwater extraction, or $20.3 \mathrm{~km}$ cubed in volume. In physical land area, the Central Valley is approximately $34 \%$ of the total area in the Sacramento and San Joaquin river basins (Famiglietti et al 2011). In addition, the Central Valley represents $1 / 6$ th of the irrigated land in the US and 1/5th of US groundwater demand, while also producing $8 \%$ of the total food produced in the United States. Groundwater loss continues to be severe in California and the surrounding states as evidenced by further GRACE measurements (See Figure 2).

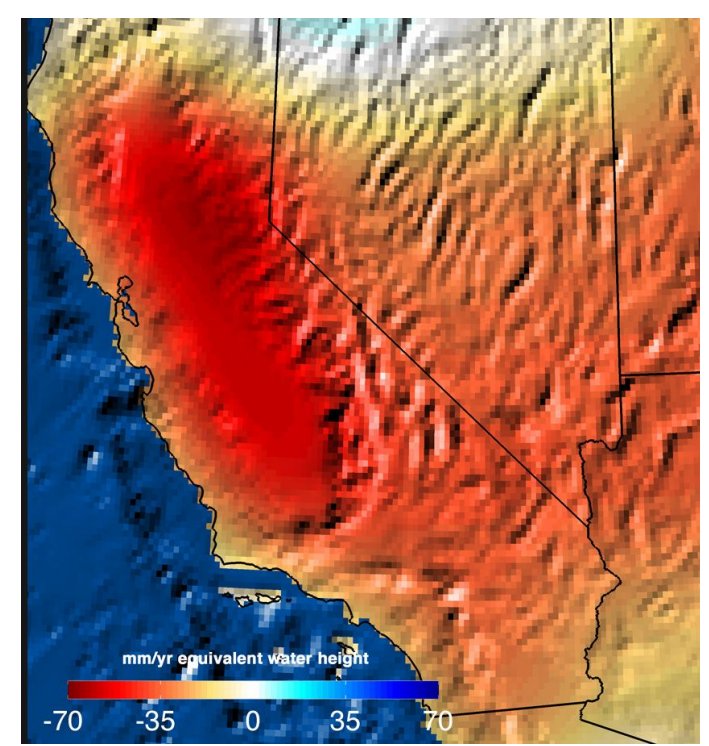

Figure 2: Trends in total water storage $(\mathrm{mm} / \mathrm{yr}$ equivalent water height) in California from NASA
GRACE satellite mission from September 2011 to September 2014 (Source: NASA JPL/Caltech (Famiglietti 2014)).

Outcomes of the study also helped shape policy and law in the state. The Sustainable Groundwater Management Act of 2014 is a landmark water legislation in California and a prominent example for intrastate, or contained, water management policy and law. Drastic levels of land subsidence due to groundwater extraction during long drought periods caused crop lands to sink up to 3 feet in some locations. Evidence of environmental harm was long-standing; California experienced escalating water issues particularly in its desert and mountainous regions. Water from the Colorado River is heavily diverted to supply domestic water needs in Southern California and agricultural needs in the Central Valley, which alone produces up to $8 \%$ of food in the continental United States. Stretches of devastating wildfires have gripped both Northern and Southern California in recent decades.

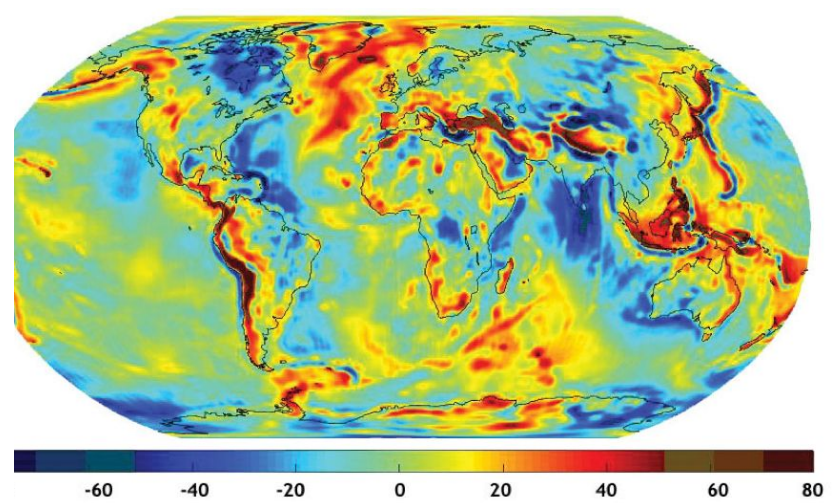

Figure 3: Gravity anomalies from ten years (2003-2013) of GRACE data ( $\mathrm{mm} / \mathrm{yr}$ equivalent water height) globally (Source: (Ries et al 2016)).

Further study is possible to a wider audience by availability of the NASA GRACE Data Analysis Tool (DAT) which was designed to allow for readily available comparisons and analysis of GRACE data without need for significant specialized knowledge. GRACE gravity maps have revealed very severe 
global water stress in groundwater resources, which are navigable through DAT. Many major basins in India, the Middle East, the Caucasus, parts of Africa, and China are undergoing severe groundwater depletion above the rate of natural recharge, including the Ganges-Brahmaputra Basin, Arabian Aquifer System, North Caucasus Basin, Congo Basin, and North China Aquifer System. Studies show that of Earth's largest 37 groundwater aquifers, 21 have exceeded sustainable use levels and are being depleted and 13 still are considered significantly distressed (Richey et al 2015). Attention to the anomalies of GRACE measurements (i.e. deviation from the mean) are instrumental in determining trends in all terrestrial water movements, including snow and ice and water (See Figure 3). NASA GRACE Follow-On (GRACE-FO) is a successor to the GRACE mission and will continue gathering vital earth observation information for future use in sustainable development and water diplomacy efforts.

\section{SMAP}

The NASA Soil Moisture Active Passive Mission (SMAP) was first launched in January 2015. Soil moisture plays an important role in the hydrological cycle and climate system by affecting processes such as atmospheric conditions and vegetation state. The system contains two passive microwave radiometers in the L-Band and measures the top 5 $\mathrm{cm}$ of the soil column with a revisit time of 2-3 days. Global soil moisture can also be measured at the C-band with monostatic radar such as in the ESA Sentinel-1 mission (Geudtner \& Torres, 2012). Problem areas for measurement include places with high surface water fraction, dense vegetation ( $>5 \mathrm{~kg} / \mathrm{m}^{\wedge} 2$ vegetation water content), and urban and mountainous areas. Soil moisture is considered a key indicator of environment health, is important to water balance budgeting, and can serve as a prelude to several natural disasters such heat waves, drought, wildfires, landslides, and downstream flooding (Chew \& Small 2018).

In map products of SMAP data, blue areas represent high relative soil moisture, often the result of heavy localized rains and flooding events (Entekhabi et al 2010). These can interpreted as saturated soil conditions in addition to possible standing water. Example of a 1,000-year storm event in South Carolina where large-scale flooding was experienced provides sample SMAP data analysis and utility (See Figure 4). Furthermore, SMAP data can be represented in terms of total soil moisture anomaly, or deviation from the mean, for a given time period. Measures of anomaly over a wide area give insight into soil moisture trends which are valuable in monitoring nationwide soil moisture conditions and helping predict crop yields, drought pre-conditions, and landslide or flooding potential (See Figure 5). Here, soils that are wetter than normal are seen as greens, and soils that are drier than normal are seen as browns.

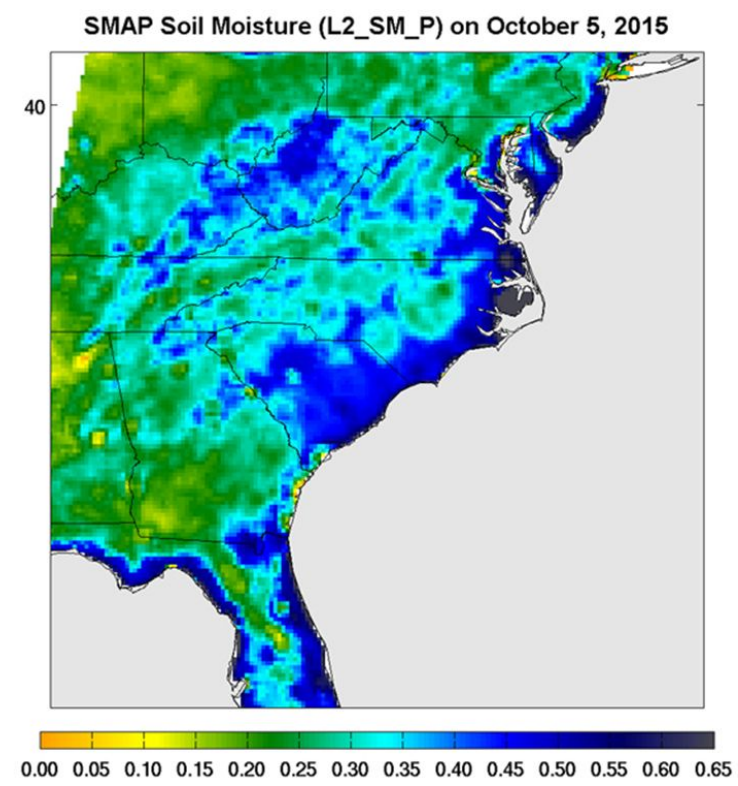

Figure 4: Surface soil moisture in the Southeastern United States as retrieved from NASA's Soil Moisture Active Passive (SMAP) satellite observatory at around 6 a.m. on October 5, 2015 (Source: NASA/JPL-Caltech/GSFC). 


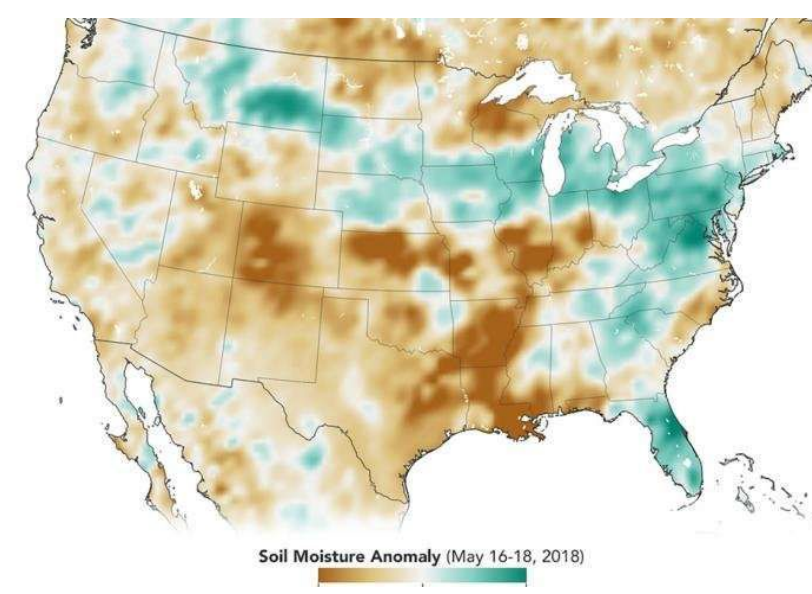

Figure 5: Nationwide map of SMAP data from May 16- 18, 2018 (Source: NASA Earth Observatory)

\section{CYGNSS}

The Cyclone Global Navigation Satellite System (CYGNSS) is a constellation of 8 small, relatively low-cost satellites quantifying the relationship between scattered L-Band - $1.575 \mathrm{GHz}$ frequency, ideal for avoiding attenuation and rain or cloud scattering - GNSS (Global Navigation Satellite System) signals and tropical ocean surface wind sensing between approximately $38^{\circ} \mathrm{N}$ and $38^{\circ} \mathrm{S}$ latitude; this range represents the critical global latitudes for tropical hurricane formation and movement (Chew \& Small 2018). CYGNSS is the first NASA satellite mission to perform satellite remote sensing of the Earth surface using exist GNSS systems, opting to utilize only the United States's Global Positioning System (GPS), though other systems exist such as the European Galileo constellation, Russia's Global Orbiting Navigation Satellite System (GLONASS), and the Chinese Beidou. In addition to measuring L-band microwave scattering from GNSS, the satellites also measure direct signals from communication satellites in order to continually locate and track the CYGNSS observatory (Ruf et al 2016). Distance between satellites is maintained by differential drag rather than propulsion, introducing cost savings and maximizing the amount of satellites in the array.
The passive radar, 4-channel receiver system has been active in low-earth orbit (LEO) since December of 2016 and is capable of surface and water measurements containing information on hurricane movements, soil moisture, and flooding over land. Raw data is processed using a calibration methodology that translates to values of the scattering cross section of the Earth. The scattering values are then converted using a retrieval algorithm to get ocean surface wind speed. Data over land are processed differently and "coherent" reflections over the surface are assumed (Ruf et al 2018). Maps are referred to as delay-Doppler maps (DDMs), and the peaks are normalized to the noise level then corrected for factors such as antenna gain, range, and transmit power. Coverage is above $70 \%$ within 24-hour time periods.

Wind speed measurements have an uncertainty of $1.4 \mathrm{~m} / \mathrm{s}$ and $17 \%$ above $20 \mathrm{~m} / \mathrm{s}$, a spatial resolution of $25 \mathrm{~km}$, and revisit time of $3 \mathrm{hr}$ and $7 \mathrm{hr}$ (median and mean). As a result of low operating frequency, CYGNSS is able to measure ocean surface wind speed under heavy precipitation conditions. Pre-launch simulated studies found examples of significant horizontal wind shear near convection associated with gust fronts driven by downdraft-induced outflows (Ruf et al 2018). Supporting data is provided by other satellite sources such as SMAP and GPM's (Global Precipitation Measurement Mission) IMERG sensor, as well as numerical weather models known as numerical weather prediction (NWP) (See Figure 6). As a relatively young satellite mission, CYGNSS data access tools hold many opportunities for improvement and enhanced public access to tracking of tropical weather patterns and distribution of water over land and sea surface. 


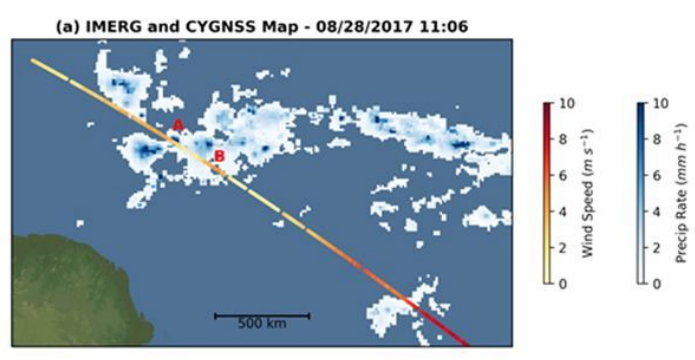

(b) IMERG and CYGNSS Time Series - 08/28/2017 11:06

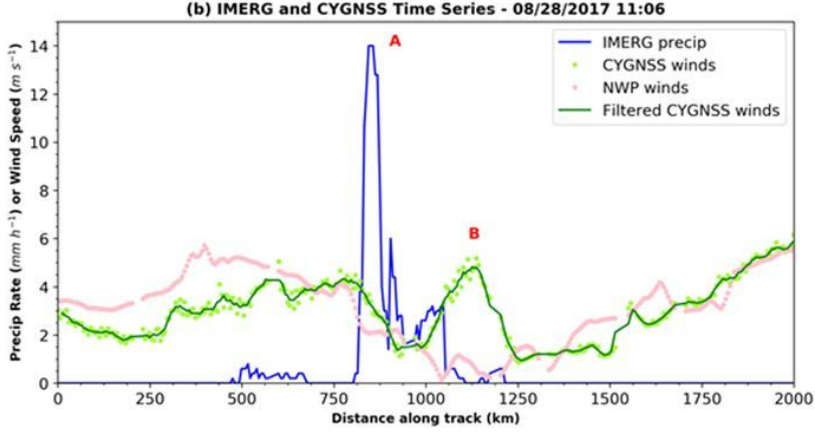

Figure 6: CYGNSS wind speed measurements across a strong convective storm towards the northeast coast of Brazil on August 28, 2017 (above). Wind and rain profile gathered from CYGNSS wind measurements, other satellite data (IMERG), and NWP modeling (below) (Source: (Ruf et al 2018)).

\section{SWOT}

Surface Water and Ocean Topography, or SWOT, is a proposed NASA mission scheduled to be launched in 2021. It is designed in non-sunsynchronous orbit to provide the first global water survey of Earth's surface water (approximately 90\% of the globe) with an onboard KA-band radar interferometer. Temporal sampling twice every 21 days will cover Earth's lakes, rivers, reservoirs and oceans. Advances in scanning lidar technology allow for ocean wave and sea surface height measurements at a maximum pulse rate at $400 \mathrm{kHz}$, with additional visible, infrared, and hyperspectral cameras as well as a GPS/IMU system (Melville et al 2016).

Studies of SWOT data simulations have been used to estimate river discharge. One method utilizes discharge observations on rivers at different locations and times to evaluate the River Kriging statistical model with regard to the SWOT mission. The correlation model outperformed other krigingbased methods with an $R$ squared value of 0.80 with indicates strong correlation (Palva et al 2015). This indicates relatively high future utility and accuracy. The SWOT mission was one of fifteen recognized as top priorities in the first decadal survey of the National Research Council and data from the mission will contribute vitally to understanding of global climate and climate change effects on water.

\section{Small Satellite Market Growth}

The small satellite trend is emerging strongly and growing as a commercial market. The "renaissance" of small satellites dates back to the 1980s, when satellites in the range of $1-500 \mathrm{~kg}$ began to advance significantly. In addition, this trend bolstered the ability of designers to formulate satellite constellations, or groups of satellites working in tandem to achieve wide coverage and parallel data processing (Xue et al 2008). Beyond size, small satellites also represent a paradigm shift in the concept of satellites to more nimble, innovative, and flexible in instrumentation. Commonly, small satellites feature standard electronic parts not necessarily intended for space deployment, which allows for lower cost and greater experimentation. This emerging market is a large opportunity for innovation and new measurement arrays capable of addressing specific water management needs and data requirements.

\section{Results and Discussion}

Through study of water governance norms, trends, and available data, the researchers show that several innovations in equitable water management are pertinent to sustainable development. Considering water stress issues in this context as well as the framework on water diplomacy is essential in assessing the associated risks of climate change. IPCC studies on mitigation 
pathways show that limitation of global warming to $1.5^{\circ} \mathrm{C}$ rather than the more probable pathways of above $2^{\circ} \mathrm{C}$ has significant implications on water stress, drought, food security, and human livelihoods. Watershed systems have regenerative, cyclic qualities that require sustainable use and measures by all party stakeholders. Shifts in paradigms have led to the recognition of water resources as a shared, transboundary management question with complex system properties. Implementation of the framework for water diplomacy for more effective water governance relies upon the availability and accessibility of data sources as the basis for water management plans. Joint-fact finding enhances the long-term water management agreement and as such, is recommended from the earliest possible stage of negotiation. Several means of water management at scale exist varying from local to watershed levels, as well as intrastate, interstate, and international mechanisms. The resolution of these scales is central to effective water management and context of the localized water stress problems. As all politics is local, so too is water knowledge. Indigenous populations and long-time residents bring vital perspectives and insights necessary for broader water management paradigms. Partnerships are an essential component of efficient management. Increased resources are available for basin-wide initiatives with the integration of partnerships, and it is additionally shown to increase likelihood of success for project completion. Transparency in data sharing bolsters partnerships and further is needed to be extended to the broader public.

The incorporation of satellite remote sensing data is urged in this endeavor. This body of earth observation information remains a vastly underutilized resource that can shed light on watershed, or "problem-shed", level issues. This community scale of work is a major opportunity for sustainable water action. The introduction of a remote sensing data-based action network for water is proposed for tracking water stress and risk. Successful models of remote sensing action networks includes the Famine Early Action Network (FEWS NET), which integrates geographic data and remotely-sensed rainfall and crop yield data. Further, tools for accessing earth observation satellite remote sensing data are needed to expand access to critical water missions such as Landsat, GRACE, SMAP, CYGNSS, and SWOT (to be launched). The broad availability of data creates synergistic effects in the spirit of the open-source collaboration and problem-solving at the localized level. Near-real time integration of water data derived from satellites is also essential because continual updates are needed with passes of respective satellites.

In addition, strategies of public communication are to be carefully examined. Several factors lead to the successful conveyance of complex systems problems such as water stress, climate change, and sustainable development. The “Day Zero' naming of the Cape Town water supply issues helped dramatically increase public concern and inclination towards action. This avenue of science communication, especially as related to uncertainty, should be explored is greater detail. Also, triggering mechanisms such as drought and cut-off water supplies tend to catapult issues into the public sphere and policy realm simultaneous. Further, tracking tools based in continuous remote sensing-based measurements would help to preempt crisis and increase readiness to deal with climate change-induced water stress as it appears. This science to policy approach represents the future for water governance in the information age.

\section{Acknowledgements}

The authors would like to extend thanks to Dr. Bennett Bearden for additional advisement. 


\section{References}

1. Burke, M., Davis, W. M. \& Diffenbaugh, N. S. (2018). Large potential reduction in economic damages under UN mitigation targets. Nature 557, 549-553.

2. Chew, C. C., and Small, E. E. (2018). Soil moisture sensing using spaceborne GNSS reflections: Comparison of CYGNSS reflectivity to SMAP soil moisture. Geophysical Research Letters, 45. https://doi.org/10.1029/2018GL077905

3. Collins, K. A., Fowlie, R. A., and Richardson, J., (2012). Securing Water Supplies in New Mexico: The Conjunctive Use Solution. World Environmental and Water Resources Congress: Crossing Boundaries.

4. Entekhabi, D., Njoku, E., O'Neill, P., Kellogg, K., Crow, W., Edelstein, W., Entin, J., Goodman, S., Jackson, T., Johnson, J., et al. (2010). The Soil Moisture Active Passive (SMAP) Mission. PROC IEEE, 98 (5):704-716.

5. Evenson, E.J., Jones, S.A., Barber, N.L., Barlow, P.M., Blodgett, D.L., Bruce, B.W., Douglas-Mankin, K., Farmer, W.H., Fischer, J.M., Hughes, W.B., Kennen, J.G., Kiang, J.E., Maupin, M.A., Reeves, H.W., Senay, G.B., Stanton, J.S., Wagner, C.R., and Wilson, J.T., (2018). Continuing progress toward a national assessment of water availability and use: U.S. Geological Survey Circular 1440, 64 p., https://doi.org/10.3133/cir1440.

6. Falkner, R., 2016. The Paris Agreement and the new logic of international climate politics. International Affairs, 95 (2), 1-28.

7. Famiglietti, J.S. (2014). The Global Groundwater Crisis. Nature Climate Change, Vol 4, pg. 945-948.

8. Famiglietti, J. S., Lo, M., Ho, S. L., Bethune, J., Anderson, K. J., Syed, T. H., Swenson, S. C., de Linage, C. R., and Rodell, M. ( 2011), Satellites measure recent rates of groundwater depletion in California's Central Valley, Geophys. Res. Lett., 38, L03403, doi:10.1029/2010GL046442.

9. Fisher, R., Patton, B., \& Ury, W. (2011). Getting to yes: Negotiating agreement without giving in (Rev. ed.). New York: Penguin Books.

10. Friedman, R. (1992). "From Theory to Practice: Critical Choices for Mutual Gains Training". Negotiation Journal. Vol 8, pg. 91.

11. G.A. Res. 51/229, at 1, U.N. Doc. AJRES/51/206 (May 21, 1997)

12. Gerston, G.N. (2010). Public Policy Making Process and Principles. New York. M.E. Sharpe, Inc.

13. Geudtner, D. and Torres, R. (2012). "Sentinel-1 system overview and performance," 2012 IEEE International Geoscience and Remote Sensing Symposium, Munich., pp. 1719-1721. doi: 10.1109/IGARSS.2012.6351191faculty_ publications/187

14. Gibson, R.B. (2001). 'Specification of sustainability-based environmental assessment decision criteria and implications for determining 'significance' in environmental assessment',
Canadian Environmental Assessment Agency

Research and Development Programme, Ottawa.

15. Huntington, J., Hegewisch, K., Daudert, B., Morton, C., Abatzoglou, J., McEvoy, D., and T., Erickson. (2017). Climate Engine: Cloud Computing of Climate and Remote Sensing Data for Advanced Natural Resource Monitoring and Process Understanding. Bulletin of the American Meteorological Society, http://journals.ametsoc. org/doi/abs/10.1175/BAMS-D-15-00324.1.

16. IPCC. (2018). [Masson-Delmotte, V., P. Zhai, H.-O. Pörtner, D. Roberts, J. Skea, P.R. Shukla, A. Pirani, W. Moufouma-Okia, C. Péan, R. Pidcock, S. Connors, J.B.R. Matthews, Y. Chen, X. Zhou, M.I. Gomis, E. Lonnoy, T. Maycock, M. Tignor, and T. Waterfield (eds.)]. Summary for Policymakers. In: Global Warming of $1.5^{\circ} \mathrm{C}$. An IPCC Special Report on the impacts of global warming of $1.5^{\circ} \mathrm{C}$ above pre-industrial levels and related global greenhouse gas emission pathways, in the context of strengthening the global response to the threat of climate change, sustainable development, and efforts to eradicate poverty. World Meteorological Organization, Geneva, Switzerland, 32 pp.

17. Islam, S. and Susskind, L.E. (2013). Ater Diplomacy: A Negotiation Approach to Managing Complex Water Networks. New York. RFF Press.

18. Kemp, R., Parto, S. and Gibson, R.B. (2005). 'Governance for sustainable development: moving from theory to practice', Int. J. Sustainable Development, Vol. 8, Nos. 1/2, pp.12-30.

19. Kiparsky, M.; Milman, A.; Owen, D.; Fisher, A.T. (2017). The Importance of Institutional Design for Distributed Local-Level Governance of Groundwater: The Case of California's Sustainable Groundwater Management Act. Water, 9, 755.

20. Lu,Y., Nakicenovic, N., Visbeck, M. and Stevance, A. (2015). "Policy: Five priorities for the UN Sustainable Development Goals". Nature. Vol 520 (7548). Pg. 432-433.

21. Maxmen, A. (2018). "Cape Town scientists prepare for 'Day Zero'," Nature. Vol 554, pg. 13-14. doi: 10.1038/d41586-018-01134-x

22. McCaffrey, S.C., (1996). The Harmon Doctrine One Hundred Years Later: Buried, Not Praised, 36 Nat. Resources J. 549. Available at: https://digitalrepository.unm.edu/nrj/vol36/iss3/5

23. Melville, W. K., Lenain, L., Cayan, D.R., Kahru, M., Kleissl, J.P., Linden, P., and Statom, N.M. (2016). The modular aerial sensing system. Journal of Atmospheric and Oceanic Technology.

24. Mitchell, M. \& Newman, M. (2002) "Complex Systems Theory and Evolution," In Encyclopedia of Evolution, ed. Pagel, M. (Oxford University Press).

25. National Research Council. 2007. Contributions of Land Remote Sensing for Decisions About Food Security and Human Health: Workshop 
Report. Washington, DC: The National Academies Press. https://doi.org/10.17226/11759.

26. Norman, E.S., Bakker, K. \& Cook, C. (2012). 'Water governance and the politics of scale: How thinking critically about scale can help create better water governance', GWF Discussion Paper 1226, Global Water Forum, Canberra, Australia. Available online at: http://www.globalwaterforum.org/2012/07/16/wat er-governance-and-the-politics-of-scale-how-thin king-critically-about-scale-canhelp-create-betterwater-governance/.

27. Paiva, R. C. D., M. T. Durand, and F. Hossain (2015). Spatiotemporal interpolation of discharge across a river network by using synthetic SWOT satellite data, Water Resour. Res., 51, 430-449, doi:10.1002/2014WR015618.

28. Pekel, J.F., Cottam, A., Gorelick, N. Belward, A.S. (2016). "High-resolution mapping of global surface water and its long-term changes." Nature, DOI: 10.1038/nature20584

29. Percival, R.V.; Schroeder, C.H.; Miller, A.S.; and Leape, J.P. (2013). "Environmental Regulation: Law, Science, and Policy, 7th edition". Book Gallery. 69. https://digitalcommons. Law. umaryland.edu/books/69

30. Rahman, M.A. (2018). The Geopolitics of Water in the Nile River Basin. Global Research.

31. Rammel, C. and van den Bergh, J.C.J.M. (2003) 'Evolutionary policies for sustainable development adaptive flexibility and risk minimising', Ecological Economics, Vol. 47, pp.121-133.

32. Richey, A.S., Thomas, B.F., Lo, M., Reager, J.T., Famiglietti, J.S., Voss, K., Swenson, S., and Rodell, M. (2015). Quantifying renewable groundwater stress with GRACE. Water Resources Research 51, no. 7: 5217- 5238. https://doi.org/10.1002/2015WR017349

33. Ries, J., Bettadpur, S., Eanes, R., Kang, Z., Ko, U., McCullough, C., Nagel, P., Pie, N., Poole, S., Richter, T., Save, H., and Tapley, B. (2016). Development and Evaluation of the Global Gravity Model GGM05, CSR-16-02, Center for Space Research, The University of Texas at Austin.

34. Rogers, P. \& Hall, A.W. (2003). Effective Water Governance. Global Water Partnership/Swedish International Development Agency, Stockholm, Sweden.

35. Ruhil, R. (2015). Millennium Development Goals to Sustainable Development Goals: Challenges in the Health Sector. International Studies, 52(1-4),118-135.https://doi.org/10.1177/002088 1717725926

36. Ruf, C. S., Chew, C., Lang, T., Morris, M. G., Nave, K., Ridley, A., \& Balasubramaniam, R. (2018). A New Paradigm in Earth Environmental Monitoring with the CYGNSS Small Satellite Constellation. Scientific reports, 8(1), 8782. https://doi.org/10.1038/s41598-018-27127-4

37. Ruf, C., P. Chang, M.P. Clarizia, S. Gleason, Z. Jelenak, J. Murray, M. Morris, S. Musko, D. Posselt, D. Provost, D. Starkenburg, V. Zavorotny. (2016). CYGNSS Handbook, Ann
Arbor, MI, Michigan Pub., ISBN 978-1-60785-380-0, 154 pp.

38. Sachs, J.S. (2012). From Millennium Development Goals to Sustainable Development Goals, The Lancet, Volume 379 , Issue 9832 , 2012, Pages 2206-2211, ISSN 0140-6736, https://doi.org/10.1016/S0140-6736(12)60685-0.

39. Sartorius, C. (2004) 'Second-order sustainability: conditions for sustainable technology development in a dynamic environment', Max Planck Institute for Research into Economic Systems, Evolutionary Economics Group, Papers on Economics and Evolution 2004-13.

40. Schleussner C-F, et al. (2016) Science and policy characteristics of the Paris Agreement temperature goal. Nat Clim Change 6:827-835.

41. Schuur, E.G., Bockheim, J., Canadell, J.G., Euskirchen, E., Field, C.B., Goryachkin, S. V., Hagemann, S., Kuhry, P., Lafleur, P.M., Lee, H., Mazhitova, G., Nelson, F.E., Rinke, A., Romanovsky, V.E., Shiklomanov, N., Tarnocai, C., Venevsky, S., Vogel, J.G., Zimov, S.A. (2008). Vulnerability of Permafrost Carbon to Climate Change: Implications for the Global Carbon Cycle, BioScience, Vol. 58(8), Pg. 701-714, https://doi.org/10.1641/B580807

42. Serbina, L., and Miller, H.M, (2014). Landsat uses and benefits-Case studies by application area: U.S. Geological Survey Open-File Report 2014-1108,61p.,http://dx.doi.org/10.3133/ofr201 41108/.

43. Stakhiv, E.Z., (2011). Pragmatic Approaches for Water Management Under Climate Change Uncertainty. Journal of the American Water Resources Association (JAWRA)47(6):11831196.DOI:10.1111/j.1752-1688.2011.00589.x

44. Stoa, R. (2014). The United Nations Water Courses Convention on the Dawn of Entry Into Force, 47 Vand. Journal Transnational Law. 1321.Available at: http://ecollections.law.fiu.edu/

45. UNESCO. (2017). Water Diplomacy: Policy Brief 1. International Centre for Water Resources and Global Change.

46. Verdin, J., Funk, C., Senay, G., \& Choularton, R. (2005). Climate science and famine early warning. Philosophical transactions of the Royal Society of London. Series B, Biological sciences, 360(1463),2155-2168.doi:10.1098/rstb.2005.17 54

47. Wood, D.R. \& Weigel, A. (2011). Building technological capability within satellite programs in developing countries, Acta Astronautica, 69(11-12), 1110-1122. https://doi.org/10.1016/j.actaastro.2011.06.008.

48. Xu, M., Jia, X., and Pickering, M. (2014) "Automatic cloud removal for Landsat 8 OLI images using cirrus band," 2014 IEEE Geoscience and Remote Sensing Symposium, Quebec City, QC, 2014, pp. 2511-2514.doi: 10.1109/IGARSS.2014.6946983

49. Yong Xue, Yingjie Li, Jie Guang, Xiaoye Zhang \& Jianping Guo (2008) Small satellite remote sensing and applications - history, current and future, International Journal of Remote Sensing, 29:15, 4339-4372, DOI: $10.1080 / 01431160801914945$ 
50. Zhang, X. (2015) Conjunctive surface water and groundwater management under climate change. Front. Environ. Sci. 3:59. doi: 10.3389/fenvs.2015.00059 